Mapping nearly a century and a half of global marine fishing: 1869 to 2015

Reg A. Watson ${ }^{* 1}$ and A. Tidd ${ }^{2}$

Keywords: global fishing, IUU, historical fishing, mapping, discards, database

*1 rwatson@ecomarres.com, Institute for Marine and Antarctic Studies, University of Tasmania, Private Bag 129, Hobart, TAS 7001, Australia;

${ }^{2}$ Orcid id : 0000-0001-8165-9699

Galway-Mayo Institute of Technology (GMIT), Old Dublin Road, Galway, Ireland.

E-mail: emperorfish@gmail.com Tel: +447740466349. 


\section{Mapping nearly a century and a half of global marine fishing: 1869 to 2015}

\section{Introduction}

Commercial or industrial fishing arguably started before recorded history when the immediate needs of fishers were sated allowing their excess catch to be traded for benefits before it perished. Now a widely traded global commodity [1], seafood is vital to world food security and prosperity, with expectations that its importance will only continue to grow with human population and climate challenges. Individual populations of harvested species can come under pressure and accessing their status and applying sufficient management control is challenging and often controversial [2]. More broadly though, in natural marine systems, there are many limitations to seafood production including the solar-powered primary productivity of supporting ecosystems $[3,4]$ and the need to maintain the irreplaceable biodiversity of these systems. The range of global industrial fleets has expanded to encompass most areas of the world's oceans[5,6]. When has the need to get up-to-date strategic overviews of global fishing operations ever been more pressing?

Several attempts at mapping broad global fishing patterns $[7,8]$ have demonstrated how this information can inform fisheries management as well as marine conservation. Past efforts have concentrated on enhancements to foundation data sources such as the United Nation's Food and Agriculture Organization (FAO) [9] which countries have contributed to since 1950. In recent years, however, a wider range of supporting data sources have become available which includes specialist regional management organizations (rFMO) such as for tuna fisheries, and exciting improvements in the tracking of fishing vessels from satellites [10]. Harmonization of data from all possible sources can only improve data quality, and for mapping, it's possible spatial precision.

Although mapped catch is now available for periods after $1950[7,8]$ this means that important fishing patterns prior to the $2^{\text {nd }}$ world war are usually ignored. Here we use available data from 1869 is combination with a new and extended compilation of new data sources including the latest satellite data such as the widely used Automatic [vessel] Identification Systems (AIS) [10] to map and visualize global fishing patterns. The scale and patterns of change for the last century and a half are revealed through a new dataset, which not only separates industrial fishing from other fishing, but documents by fishing country and associated fishing gear, the entire catch including estimates of illegal, unreported and discarded catch.

\section{Methods}

\subsection{Data sources, scope and overview}

Input data was sourced from publicly available websites (Table 1.). All sources but the tuna regional management organization's (tuna rFMO) data and Global Fishing Watch's (GFW) vessel Automatic Identification System (AIS)-based data[10] were used initially in a similar fashion to [7] and summarised below to map reported landings to candidate 30-min spatial cells with a global grid (Supplementary Fig. 1). This included a separation of deemed industrial from non-industrial reported landings. Following this there was reevaluation and filtering of reported landings initially assigned to candidate spatial cells through the use of distributional information related to the associated fishing gear used, and where applicable, the tuna rFMO and AIS positional data (Table 1.) Subsequently this map of reported landings 
was extended through estimates for reported, Illegal, Unreported and Unregulated (IUU) catch and associated discards for both the industrial and non-industrial sectors. The global Human Development Index (HDI) [11] was used to assist estimation of IUU associated with non-industrial fisheries, and served as a simple available proxy for reporting likelihood.

Only records of taxa with a marine origin were used - although some are found in other habitats. Where possible aquaculture production was excluded as were records describing shells, coral, amphibians, reptiles, birds and mammals.

\subsection{Initial mapping}

FAO data for the period 1950 to 2015 was combined and coded with a range of other input sources for reported fisheries landings as described in [7] (Table 1.). Overlapping records were removed, and only the most spatially specific data was retained. Mapping involved using all means to identify the most specific taxonomy of the reported landing datum because this established both the potential range of fished spatial cells, but also a gradient based on the rough abundance of the fished taxa related to critical habitats, ocean depths etc. [12]. Within the statistical area reported in source databases, usually only a subset of spatial cells were accessible to the fishing fleets of the reporting country [13]. This is because most global catch is taken within the claimed exclusive economic zone (EEZ) waters of countries where the access of foreign fishing fleets is regulated and usually documented.

\subsection{Separation to industrial and non-industrial sectors}

The separation of landings from industrial and non-industrial fishing was based on a number of factors. The first was whether the taxa had a clear association to fishing gear typically not used in non-industrial fishing such as with tuna purse seine operations. Additionally, for each country the division was further derived by the relative association of the taxon described as landing by the two fishing sectors during the period of fishing by published catch reconstructions [8]. In addition, where the fishing occurred was considered important to the likely association with a fishing sector. Non-industrial fishing is typically accepted to occur within $200 \mathrm{~km}$ of shore and within $50 \mathrm{~m}$ of depth [14]. Division to sectors is acknowledged to be an imperfect science without detailed and specific data such as from logbooks, surveys etc. which unfortunately are not available for a global assessment. 


\section{Table 1. Data sources}

\begin{tabular}{|c|c|c|}
\hline Source & Description & Link \\
\hline ICES & $\begin{array}{l}\text { International Committee for the Exploration of the Sea } \\
\text { 1950-2015 } \\
\text { Historical data 1903-1949 }\end{array}$ & www.ices.dk \\
\hline NAFO & $\begin{array}{l}\text { Northwest Atlantic Fisheries Organisation Catch and } \\
\text { Effort 21B 1960-2015 (Updated } 1 \text { June 2017) }\end{array}$ & www.nafo.int \\
\hline SEAFO & $\begin{array}{l}\text { Southeast Atlantic Capture Production 1975-2015 (FAO } \\
\text { Regional Capture Fisheries Statistics v2017.2.0 Release } \\
\text { date: } 15 \text { June 2017) }\end{array}$ & www.seafo.org \\
\hline GFCM & $\begin{array}{l}\text { General Fisheries Commission for the Mediterranean } \\
\text { Capture production 1970-2015 STATLANT 37A } \\
\text { (Release date: Sept 2017) }\end{array}$ & $\begin{array}{l}\text { http://www.fao.org/gfcm/data/capture- } \\
\text { production-statistics/en/ }\end{array}$ \\
\hline CECAF & $\begin{array}{l}\text { Fishery Committee for the Eastern Central Atlantic } \\
\text { Capture production 1970-2015 (FAO Regional Capture } \\
\text { Fisheries Statistics v2017.2.0 Release date: } 15 \text { June } \\
\text { 2017) }\end{array}$ & www.fao.org/fishery/rfb/ecaf \\
\hline CCAMLR & $\begin{array}{l}\text { Commission for the Conservation of Antarctic Marine } \\
\text { Living Resources Statistical Bulletin } 2017 \text { Vol. } 29 \text { 1970- } \\
2015\end{array}$ & www.ccamlr.org \\
\hline SAUP & $\begin{array}{l}\text { Sea Around Us project - records for FAO area } 18 \\
\text { (Arctic) v2 1950-2014 (extrapolated to 2015) }\end{array}$ & www.seaaroundus.org[8] \\
\hline WCPFC & $\begin{array}{l}\text { Western \& Central Pacific Fisheries Commission 1950- } \\
2014 \text { (Data accessed June 2017) }\end{array}$ & https://www.wcpfc.int/ \\
\hline IOTC & $\begin{array}{l}\text { Indian Ocean Tuna Commission 1952-2015 (Data } \\
\text { accessed June 2017) }\end{array}$ & http://www.iotc.org/ \\
\hline ICCAT & $\begin{array}{l}\text { International Commission for the Conservation of } \\
\text { Atlantic Tunas 1956-2015 (Data accessed June 2017) }\end{array}$ & https://www.iccat.int/en/ \\
\hline IAATC & $\begin{array}{l}\text { Inter-American Tropical Tuna Commission 1954-2015 } \\
\text { (Data accessed June 2017) }\end{array}$ & https://www.iattc.org/HomeENG.htm \\
\hline CCSBT & $\begin{array}{l}\text { Commission for the Conservation of Southern Bluefin } \\
\text { Tuna 1965-2015 (Data accessed June 2017) }\end{array}$ & https://www.ccsbt.org/ \\
\hline GFW & Global Fishing Watch AIS global data 2016 & http://globalfishingwatch.org/[10, 15] \\
\hline
\end{tabular}




\begin{tabular}{|l|l|l|}
\hline $\begin{array}{l}\text { Mitchell, } \\
\text { B.R. }\end{array}$ & International Historical Statistics: The Americas 1750- & {$[16]$} \\
& $\begin{array}{l}\text { International Historical Statistics: Africa, Asia \& Oceania, } \\
1750-1993\end{array}$ & {$[17]$} \\
& & \\
\hline
\end{tabular}

\subsection{Estimation of IUU and associated discards}

As in [7], estimates of IUU and associated discards were made for each record of reported landings. For the industrial sector records the current procedure was largely unchanged. The relative association of landings with a range of fishing gears was made based on the fishing country, the year of fishing and the fished taxa [18]. This allowed published data on rates of IUU and discarding to be used $[19,20]$ to guide estimation of the missing components so that the complete catch could be estimated, and not simply reported landings.

For the non-industrial sector it was clear that in order to achieve the published catch rates [14], as well as the national estimates for this sector published as country reconstructions [8], that the unreported component (IUU) of non-industrial fishing was significant. It was decided that the level of non-reporting in this sector to FAO and other parties was influenced by the national resources available for government monitoring. Therefore, the estimation of IUU for this sector was adjusted by country HDI [11], with poorer countries having relatively a larger portion of unreported landings. This expected association was verified by examining the breakdowns within country reconstructions [8] where we found a significant relationship with $\mathrm{R}^{2}=0.29$.

\subsection{Adjustment for associated fishing gear logistics}

It was possible to associate each fishing record with a range of fishing gears using the fishing year, country and the fished tax on as described in $[7,18]$. Each fishing gear was deemed to have a general global pattern of probable spatial distribution largely based on distance offshore, depth of water and the distributions of target taxa as summarised from previous mapping of catch and fishing effort [7,21]. For non-industrial fishing, a single distribution was considered, which favoured the published association with nearshore and shallow areas [14].

The fishing gear logistics distribution was used to filter and redistribute catch associated with spatial cells in earlier processing. This further processing would, for example, rule out sites far off shore for non-industrial fishing by proportionately increasing landings associated with nearshore candidate cells. The purpose was to enforce some rational and realistic consideration of gear-based logistic cost/benefit constraints on mapped solutions which has been missing in previous mapped database versions $[7,8]$. 


\subsection{Adjustment for tuna fisheries}

For tuna fisheries, there exists greater mapping challenges and opportunities than for most other fisheries which are largely inshore. Tuna fisheries encompass all tropical and subtropical seas but each year, depending on the oceanographic conditions and any fishing access agreements negotiated by roving fleets, the focus of fishing can be in vastly different areas within the broad range of the fished taxa. Data from FAO and other sources has always been instructive to focus catch mapping to specific locations, as is the data made available by tuna rFMOs (Table 1.). Annual distributions, often in 1-degree or 5-degree spatial areas were used to improve the redistribution of spatial mapping from initial processing for the appropriate tuna taxa and associated fishing gears.

\subsection{Adjustment using satellite data}

Most recently it has been possible to track the movement of large vessels at sea from satellites. Though there are dedicated systems such as satellite vessel monitoring systems (VMS) used extensively in fisheries management, these data are not widely available nor do they cover most global fishing operations. Most recently the use of AIS positional vessel tracking has shown promise. With considerable processing, it has even been possible to determine not only if the vessel is a fishing vessel but even something about the associated fishing gears used and possibly vessel size [10]. Unfortunately, the AIS coverage has only become good in 2016 and is still weak in some areas such as SE Asia due to many factors [15]. Where possible, however, especially for offshore fishing for tuna, these data can add another valuable source of information about fishing distributions. AIS data from 2016 was used to constrain the mapping of relevant catches for 2015 and, with reducing effect, for fishing years back to 2010 . Before 2010 it was considered that recent AIS data could not improve mapping procedures.

\subsection{Mapping historical data (pre-1950)}

A number of data sources describe country fisheries landings, sometimes by taxa, as early as Roman times. In limited cases, reconstructions exist for some stocks such as Atlantic herring and cod for nearly 1000 years[22]. Here the sources described in Table 1 were used as the basis for extending mapped reported landings to 1869. The procedure used was similar to that described for more recent (post-1950) industrial fisheries (above). The spatial guide used was based on the same reporting country and fished taxon in 1950. If there was no such matching record then the time period used was generalized to any fishing in the $1950 \mathrm{~s}$. If this failed then the fished taxon was generalized to a broader taxonomic range. Using this method, it was possible to map all available historical records.

\subsection{Data structure and availability}

In order to facilitate access to the data described, all the mapped data has been made available for public download (DOI 10.4226/77/5a65572655f73 ; http://data.imas.utas.edu.au/portal/search?uuid=ff1274e1-c0ab-411b-a8a25a12eb27f2c0). The mapped catch data consists of ASCII records in 5-year blocks with structures described in Supplemental Material. 


\section{Results and discussion}

\subsection{Coverage}

Using the described sources and methodology it was possible to assemble a mapped global database of reported landings of industrial fishing with estimates of their associated IUU and discards for 1869 to 2015 inclusive (Fig. 1A). Before 1950 reported landings were assumed to come from industrial or commercial fisheries. Before the start of FAO's reporting in 1950 (Fig. 1.B) there were much lower levels of reported landings and hence their associated IUU and discards were much smaller. There was an early peak in reported fishing in the 1930-40s before the significant reduction during the $2^{\text {nd }}$ world war clearly seen in the time series. After the war, global reports of fisheries landings quickly returned to prewar levels with a steep and constant rise until maximum levels of the 1980-90s. Following this, levels have been fallen slightly despite increasing fishing effort $[21,23]$.

After 1950 It was possible to make separate estimates for the industrial and non-industrial sectors (Fig. 1C). Though of greater uncertainty, the non-industrial sector is significant and may play a greater role in the domestic supply of protein in some countries than catch from industrial fishing.

Putting all components of catch from both major sectors together (Fig. 1D) their relative magnitude becomes clear. Global estimates of marine fisheries catch in recent years has not increased much after steady increase from 1949 to the late 1980s. More than half of global marine catch is taken by industrial fisheries and now described in international reporting systems such as by the United Nation's FAO databases which collate national data from reporting countries [9].

We estimate that the $2^{\text {nd }}$ biggest component of global marine catch is that currently unreported by non-industrial fisheries, though the discards and IUU of industrial fisheries are almost the same magnitude. Globally many fisheries that are managed have been compelled to reduce discarding and to increase the proportion of catch that is reported. In some countries, particularly with tropical bottom trawling, what was once discarded is returned to shore to feed aquaculture operations. This could be a significant and growing trend as tropical trawling is extensive [24]. This change to 'discarding' practices increases efficiency in the human-use of killed fauna but also increases net export of biomass from marine systems with unknown consequences. Indeed, this value-added practice may even increase the collateral damage caused by fishing even reducing incentives for other changes such as increasing gear specificity that would protect vulnerable non-target species. 

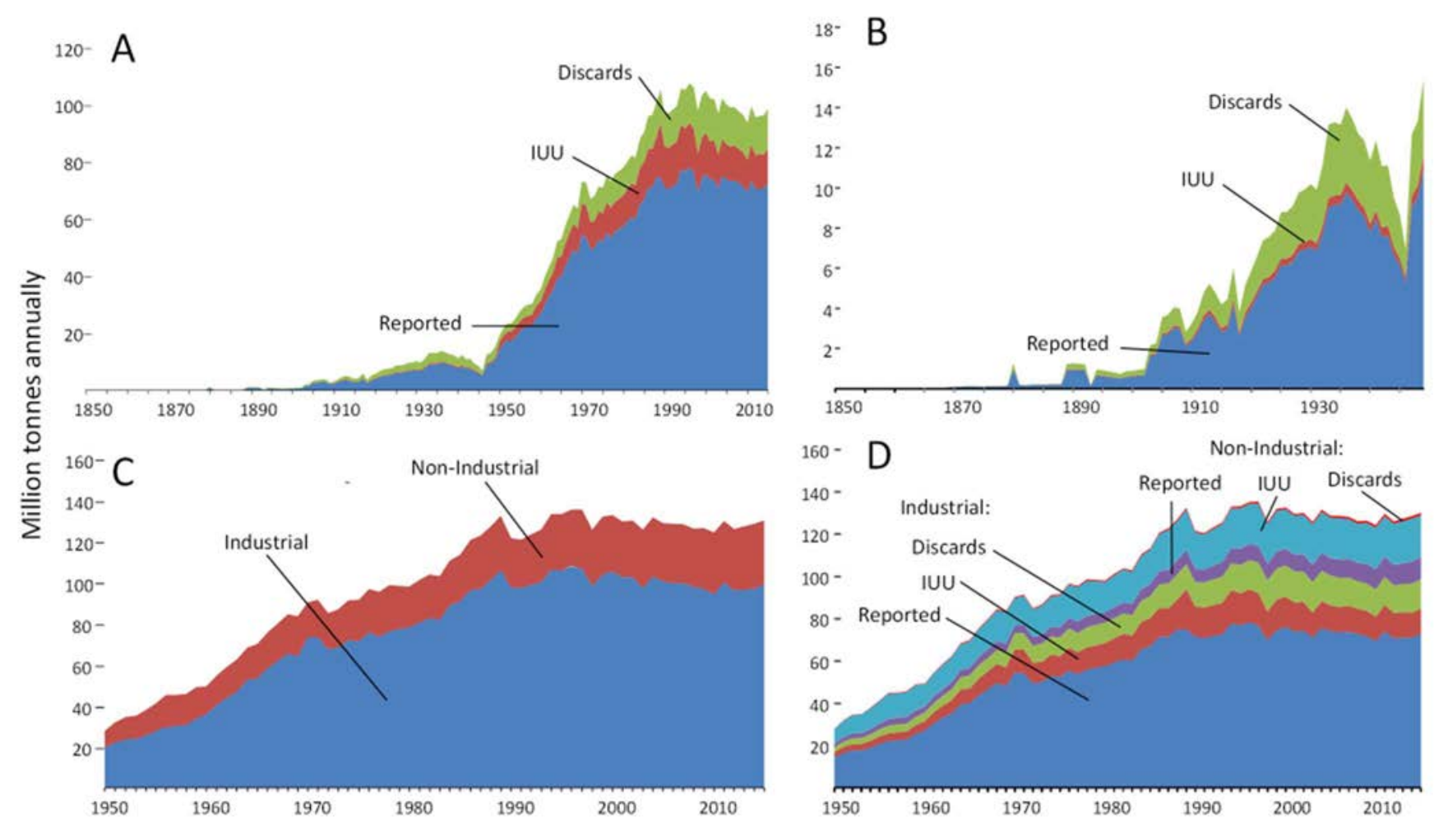

Fig. 1: Global catch and landings (million tonnes) for A available reported landings from industrial fisheries showing reported, IUU and discards, B shows expanded view of industrial catch from 1986 to $1950, \mathrm{C}$ breakdown to industrial and non-industrial sectors and D breakdown of industrial and non-industrial catch from 1950 to 2015.

\subsection{Mapping industrial marine catch since 1869}

Though the global geographic scope of industrial fishing was undoubtedly limited before the 1900s, the reporting was similarly poor. Records available to us include just three fishing countries: Canada, the USA and Japan (Fig. 2a). Reported landings, even when adjusted for likely underreporting and discarding were much lower than the current intensity of fishing (note units for Fig. 2a and b are in kg whereas for Fig. $2 \mathrm{c}$ and $\mathrm{d}$ they are in tonnes).

By the early 1900s more countries were collecting national fisheries landings statistics (Fig 2b) and ICES has a historical time series of landings in the European seas which still continues from that time. Most fisheries were coastal in nature and the majority of fishing vessels had a limited endurance because of a range of factors including the challenges of preserving the catch. There were exceptions such as the very long voyages for cod which was readily accepted salted [25].

Just before and since the $2^{\text {nd }}$ world war (Fig. 2c) there was a vast expansion of global fishing fleets. Fishing intensified inshore but, moreover, fleets now pursued large pelagics like tuna species across entire oceans. Fishing deeper allowed fishing down the continental slope and to distant seamounts[26, 27], however, some of these deeper stocks were not as productive as initially thought [28]. It was then feasible to fish in polar regions but it soon became accepted that while some species such as krill appeared to have great potential, others were long-lived species requiring careful management. Many regional and international 
management agencies began during this period as fleets travelled increasingly greater distances [6], and deals were struck for access to the declared exclusive economic zones of 200-nautical miles that most countries claimed. During this time many poorer countries reduced their commercial fishing [29] and allowed the access of foreign fleets but it was not always to their advantage to do so [30, 31].

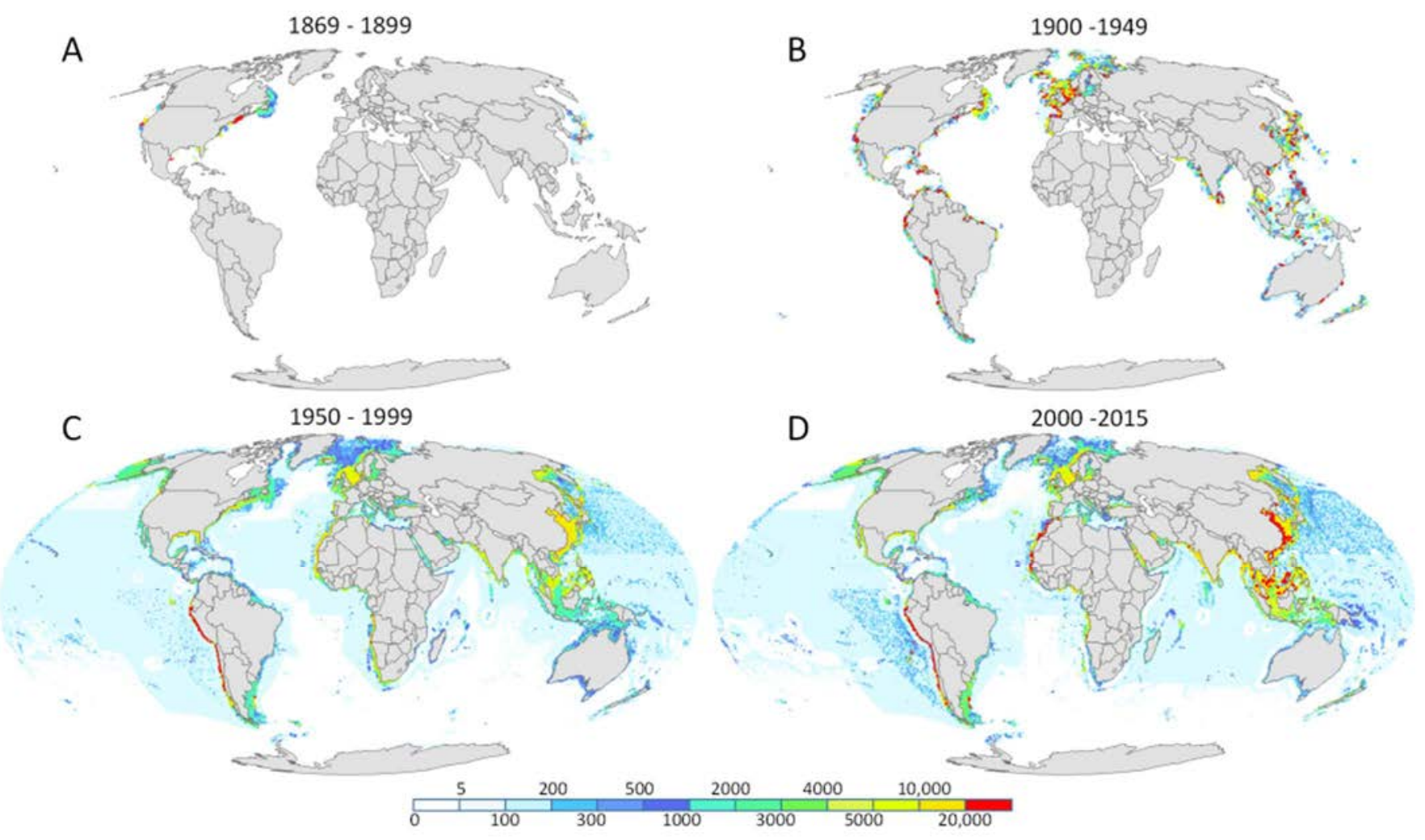

Fig. 2: Map of average annual reported landings for A 1869-1899, B 1900-1949, C 19501999 and D 2000-2015. Units for A and B are kg but for C and D are tonnes per year.

By 2000 (Fig. 2d), fisheries had generally intensified, particularly in the Asian region but also in many other locations. While management in some areas limited expansion, there was little control in other places as levels of effective fisheries management varied greatly [32]. The increased use of waters along the African north-west and west coast by initially European fleets (sometimes involving reflagging) [29] was compounded by fleets from Asia[33]. Catches did not increase despite the additional fishing intensity and the increasing area of the oceans fished [21,34]. A greater portion of the finite marine ecosystem primary productivity was directed to harvested seafoods than ever before. Substantial increases to fish and seafood consumption was increasingly being supported by expansions to marine and freshwater aquaculture, although feed for these farms often came from marine stocks forage fishes. While important to farming fish these species, often small pelagics, have important roles in marine food web $[35,36]$ and support marine mammals and seabirds [37]. 
In Fig. $2 \mathrm{c}$ and $\mathrm{d}$ it is clear that the inclusion of additional spatial information form tuna rFMOs and from the AIS satellite data more recently has allowed relative hot-spots of fishing on the high seas to be highlighted more precisely than previous attempts [7]. Increases to spatial precision will have special significance to investigations of the interaction of fisheries and sensitive habitats and/or wildlife. Because fisheries can consume the same species as marine predators it is important to be able to make use of all spatial detail available [37-40] as the energetics of foraging by some species are not nearly as generous as fossil fuels allow fishing fleets.

\subsection{Country share of global reported industrial landings}

During the develop of global marine fishing over the last century and a half, the dominance of individual countries has changed many times. No doubt greatly influenced by what reporting records were available, initially Canada and the USA dominated the world as well as Japan (Fig. 3a). By the 1900s, more countries were reporting (35 in total) (Fig. 3b). The UK joined Japan and the USA to have the greatest shares of the increasing global landings.

Since 1950 there have been 192 reporting 'countries'. Japan was the leader in period to 2000 (Fig. 3c) followed by the USSR (as it then was), Peru (where anchoveta stocks supplied one of the world's most productive fisheries) followed by China, USA, Canada and India.

Since then (Fig. 3d) China has continued to increase its fishing fleets and landings and now dominates. While Peru's anchoveta fishery were still important there were also huge volumes landed in Alaska of Pollock - also used primarily as a fodder fish. 

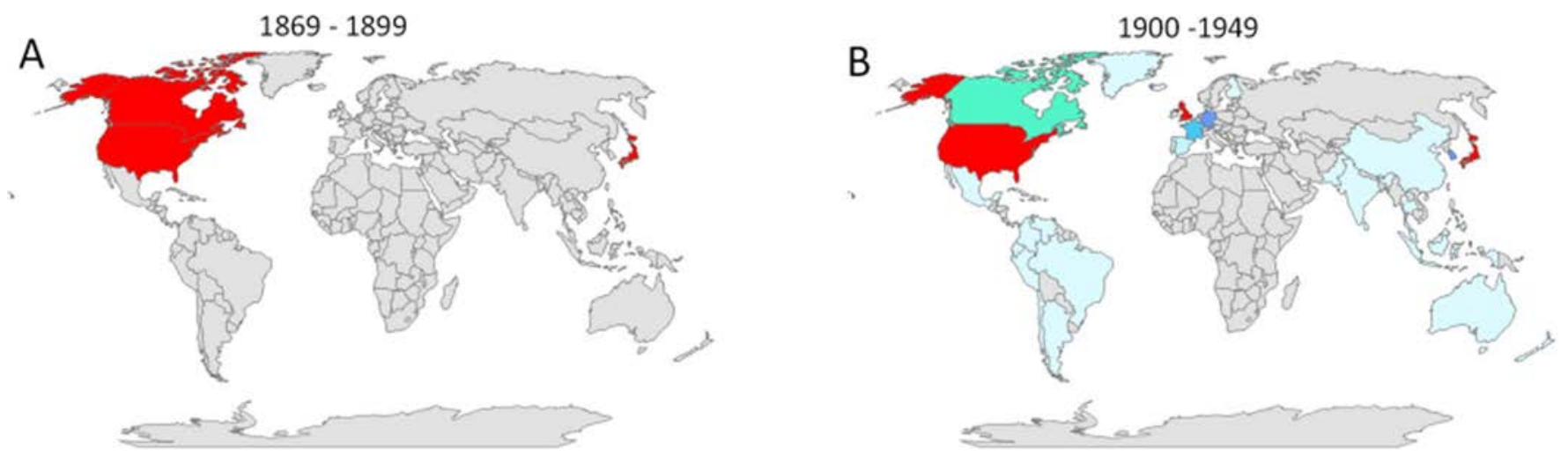

C
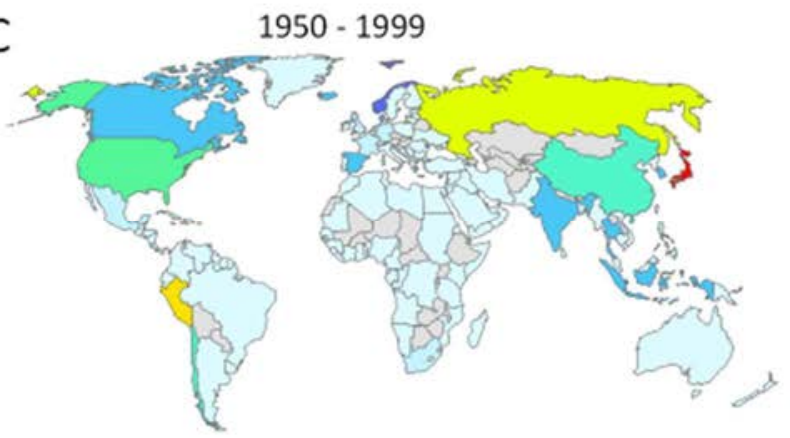

D
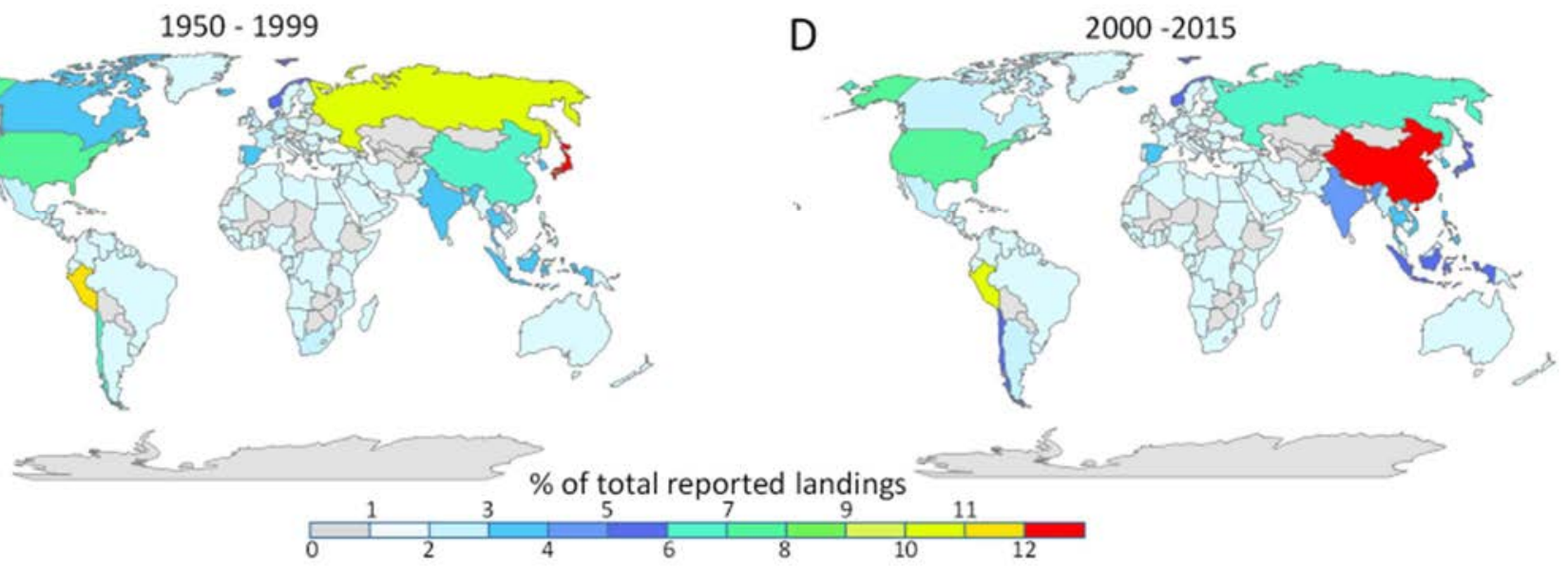

Fig. 3: map of country percentage share of average annual reported landings for A 1869-1899 (3), B 1900-1949 (35), C 1950-1999 (192) and D 2000-2015 (192) where the number indicates the number of reporting countries in the period.

\subsection{Composition of global industrial catch since 1869}

The composition of global marine catch has changed since the 1880 s (Fig. 4a). Although less is known about catch composition before 1900, most landings were demersal fishes though there have always been reported landings of small pelagics for at least 800 years [22]. Following the industrial expansion post World War II, fisheries landings increased and included in this was a vast expansion of small pelagics such as come from the rich upwelling areas, which were then intensively fished. In more recent years there has been a relative expansion of valuable landings of tunas, shrimps and squid reflecting the ability of fleets to roam widely, work at night and use energy intensive method of fishing supported by modern technology and attempt to meet increasing demands for varied seafoods. 

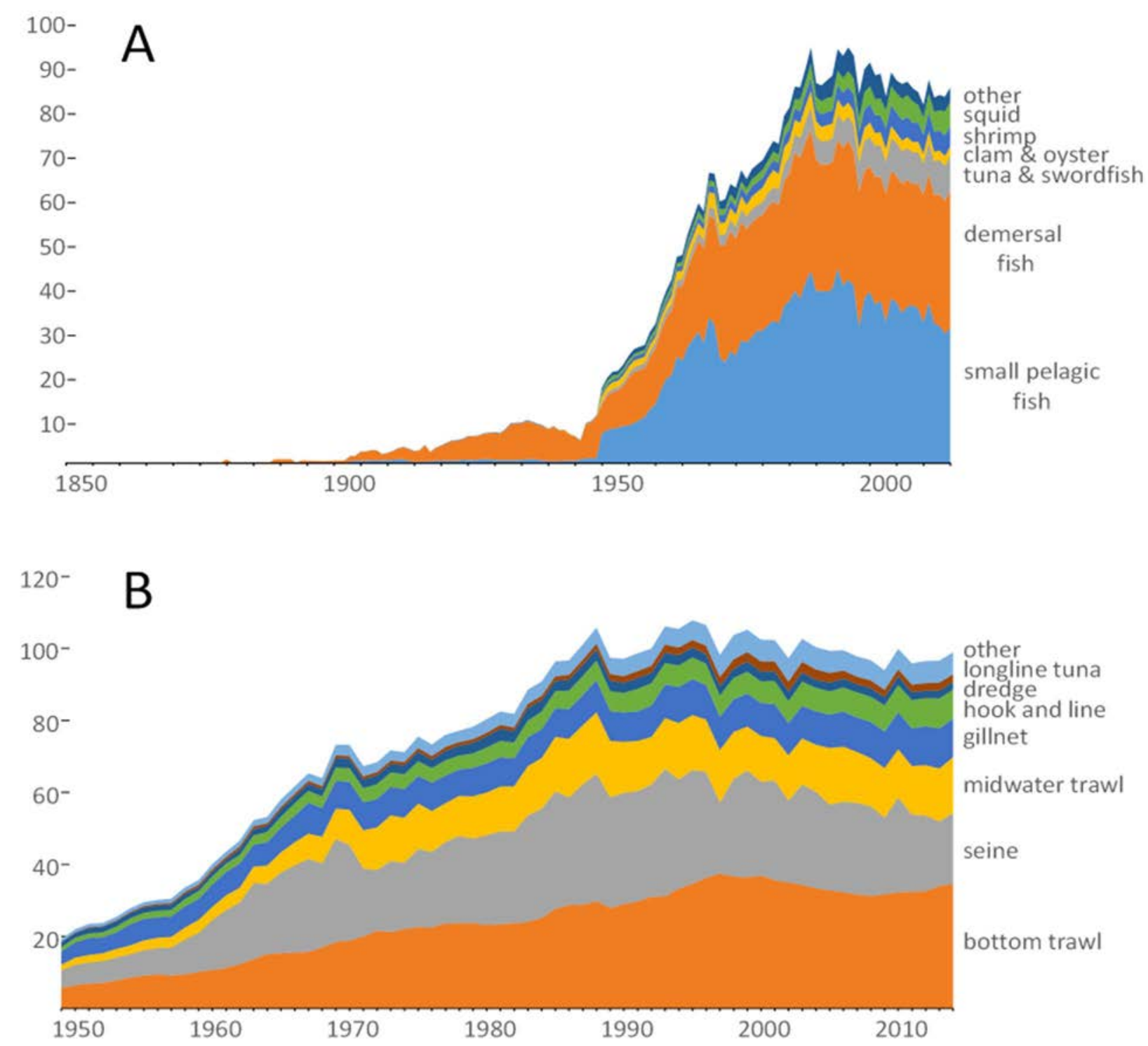

Fig. 4. Breakdown of global industrial catch A by major taxonomic groups and B by the associated fishing gears used.

\subsection{Fishing gears associated with global catch}

Association of fishing gear with catch shows that the relative use of fishing gears has changed since 1950 (Fig. 4b). Proportionately, the most obvious change is the increase in bottom trawling [24] while the use of seine fishing gear appears to have declined. Midwater trawling which requires guidance by newer technologies such as sophisticated sonar arrangements has also increased. This does suggest that although our use of energy to fish has been high for decades it may have continued to increase $[41,42]$. Bottom trawling has additional implications to marine habitats as it has high levels of non-targeted catch and is well known to often damage or even remove important substrates and sessile organisms. 


\section{Conclusions}

Mapping global marine catch is very important for a variety of reasons, not least because the push to increase wild fish capture often appears to conflict directly with the accepted need to maintain marine ecosystems at their most diverse, resilient and productive causing much division in the marine science community. Perhaps best tackled at a smaller scale (national or less) it is nevertheless valuable to get an all-inclusive overview if possible, and to see how things have changed over time [43]. The challenges are great in inshore waters; however, they now increasingly extend to high seas areas and to greater depths [44]. Indeed, of necessity, more and more fishing and marine conservation interests have become partners of mutual concern as marine resources are pursued by mining, petroleum and other industries. Who would have imagined that the petroleum industry's widely used seismic survey methods could kill the zooplankton vital to marine ecosystems [45]? Though some estimate that our living marine resources such as mesopelagics may be huge [46], it remains that understanding the marine food web is vital, including through detailed mapping, to avoid overestimating what can be safely removed. We will have to know much more before we dare sequester greenhouse gases into the ocean depths.

With climate change comes new challenges. The distribution and productivity of stocks currently suppling seafood and income to many of the world's populations will likely change [47, 48]. In all likelihood, there will be interest in adjusting ocean acidity and sequestering greenhouse gases in the oceans. These activities will have international, and as yet, poorly understood impacts on marine systems and the services we currently depend on. We must continue to use all technologies to maintain productive and diverse marine environments if we want the future food security that the sea can provide. The increasingly sophisticated data processing of AIS inputs is rapidly increasing their contribution to monitoring global fishing[49]. Future surveillance will include greater use of satellite technology such as NOAA's Visible Infrared Imaging Radiometer Suite (VIIRS) to add 'night vision' to the sophisticated repurposed data coming from other vessel signals such as AIS. Unique QR codes for valuable fish projects combined with block chain technologies will strengthen traceability and help combat illegal fishing. These technologies and more will also be vital if marine protected areas are used to protect offshore areas $[10,15]$ where patrols are costly or ineffective. Managing conflicting uses will be very challenging in remote areas because marine resources will only become more valuable.

Humans have had a long association with marine resources, indeed, they may have ensured our very survival in the past [50] but our use of marine resources through fishing has changed remarkably since the 1800 s. We can learn much from looking at historical patterns of fishing, and they can help us make decisions vital to maintaining the marine resources and their environments that we all depend on - now and in an uncertain future.

Acknowledgements

The authors acknowledge the support of the Australian Research Council (Discovery project DP140101377). We are grateful to Global Fisheries Watch and particularly D. Kroodsma for access to processed satellite data. 
References

[1] J.L. Anderson, F. Asche, S. Tveterås, World Fish Markets, in: R.Q. Grafton, R. Hilborn, D. Squires, M. Tait, M. Williams (Eds.), Handbook of

Marine Fisheries Conservation and Management, Oxford University Press, Oxford, 2009, p. 784.

[2] B. Worm, R. Hilborn, J.K. Baum, T.A. Branch, J.S. Collie, C. Costello, M.J. Fogarty, E.A. Fulton, J.A. Hutchings, S. Jennings, O.P. Jensen, H.J. Lotze, P.M. Mace, T.A. McClanahan, C. Minto, S.R. Palumbi, A.M. Parma, D. Ricard, A.A. Rosenberg, R. Watson, D. Zeller, Rebuilding global fisheries, Science 325(5940) (2009) 578-585.

[3] E. Chassot, S. Bonhommeau, N.K. Dulvy, F. Mélin, R. Watson, D. Gascuel, O. Le Pape, Global marine primary production constrains fisheries catches, Ecology Letters 13(4) (2010) 495-505.

[4] R.A. Watson, D. Zeller, D. Pauly, Primary Productivity Demands of Global Fishing Fleets, Fish and Fisheries 15 (2014) 231-241.

[5] T. Morato, R. Watson, T.J. Pitcher, D. Pauly, Fishing down the deep, Fish and Fisheries 7(1) (2006) 24-34.

[6] R.A. Watson, G. Nowara, K. Hartmann, B.S. Green, S. Tracey, C.G. Carter, Marine foods sourced from farther as their use of global ocean primary production increases., Nature communications 6(7365) (2015).

[7] R. Watson, A database of global marine commercial, small-scale, illegal and unreported fisheries catch 1950-2014., Nature Scientific Data 4(170039) (2017).

[8] D. Pauly, D. Zeller, Catch reconstructions reveal that global marine fisheries catches are higher than reported and declining, Nature communications (2016).

[9] FAO, Fisheries and Aquaculture Department: Statistics Introduction, 2017. http://www.fao.org/fishery/statistics/en. (Accessed 12 January 2018 2018).

[10] E.N. de Souza, K. Boerder, S. Matwin, B. Worm, Improving Fishing Pattern Detection from Satellite AIS Using Data Mining and Machine Learning, PLOS ONE 11(9) (2016) e0163760.

[11] UNDP, Human Development Index (HDI), 2017.

http://hdr.undp.org/en/content/human-development-index-hdi. (Accessed 12 January 2018 2018).

[12] C. Close, W.L. Cheung, S. Hodgson, V. Lam, R. Watson, D. Pauly, Distribution ranges of commercial fishes and invertebrates., in: M.L.D. Palomares, K.I. Stergiou, D. Pauly (Eds.)

Fisheries Centre Research Reports, Fisheries Centre, University of British Columbia, Vancouver, Canada, 2006, pp. 27-37.

[13] R. Watson, A. Kitchingman, A. Gelchu, D. Pauly, Mapping global fisheries: sharpening our focus, Fish and Fisheries 5(2) (2004) 168-177.

[14] R. Chuenpagdee, L. Liguori, M.L.D. Palomares, D. Pauly, Bottom up, global estimates of small-scale marine fisheries catches, in: T.J. Pitcher (Ed.) Fisheries Centre Research Reports, University of British Columbia, Vancouver, Canada, 2006, p. 105pp.

[15] M. Robards, G.K. Silber, J.D. Adams, J. Arroyo, D. Lorenzini, K. Schwehr, J. Amos, Conservation science and policy applications of the marine vessel Automatic Identification System (AIS) - a review, Bulletin of Marine Science 92(1) (2016) 75-103.

[16] B.R. Mitchell, International Historical Statistics: The Americas 1750-1988, 2nd ed., Palgrave MacMillian, UK, 1993. 
[17] B.R. Mitchell, International Historical Statistics: Africa, Asia \& Oceania, 1750-1993, 3rd ed., Palgrave Macmillan, UK, 1998.

[18] R. Watson, C. Revenga, Y. Kura, Fishing gear associated with global marine catches: I Database development., Fisheries Research 79 (2006) 97-102.

[19] D.J. Agnew, J. Pearce, G. Pramod, T. Peatman, R. Watson, J.R. Beddington, T.J. Pitcher, Estimating the worldwide extent of illegal fishing, PLoS One 4(2) (2009) e4570.

[20] K. Kelleher, Discards in the world's marine fisheries. An update., FAO Fisheries Technical Paper, FAO, Rome, 2005, p. 131.

[21] R.A. Watson, W.W.L. Cheung, J.A. Anticamara, R.U. Sumaila, D. Zeller, D. Pauly, Global marine yield halved as fishing intensity redoubles, Fish and Fisheries 14 (2013) 493-503.

[22] R.A. Watson, T.J. Pitcher, S. Jennings, Plenty more fish in the sea?, Fish and Fisheries 18 (2017) 105-113.

[23] J.D. Bell, R.A. Watson, Y. Ye, Global fishing capacity and fishing effort from 1950-2012, Fish and Fisheries 18(3) (2017) 489-505.

[24] R. Watson, C. Revenga, Y. Kura, Fishing gear associated with global marine catches. II. Trends in trawling and dredging, Fisheries Research 79 (2006) 103-111.

[25] M. Kurlansky, Cod: a biography of the fish that changed the world. , Walker, New York, 1997.

[26] R. Watson, A. Kitchingman, W.W. Cheung, Catches from world seamount fisheries, in: T.P. Pitcher, T. Morato, P.J.B. Hart, M.R. Clark, N. Haggan, R.S. Santos (Eds.), Seamounts: Ecology, Fisheries \& Conservation, Blackwell, Oxford, UK, 2008, pp. 400-412.

[27] R.A. Watson, T. Morato, Fishing down the deep: accounting for within-species changes in depth of fishing., Fisheries Research 140 (2013) 63-65.

[28] E.A. Norse, S. Brooke, W.W.L. Cheung, M.R. Clark, I. Ekeland, R. Froese, K.M. Gjerde, R.L. Haedrich, S.S. Heppell, T. Morato, Sustainability of deep-sea fisheries, Marine Policy 36(2) (2012) 307-320.

[29] J. Atta-Mills, J. Alder, U.R. Sumaila, The decline of a regional fishing nation: The case of Ghana and West Africa, Natural Resources Forum 28 (2004) 13-21.

[30] R. Nichols, S. Yamazaki, S. Jennings, R.A. Watson, Fishing access agreements and harvesting decisions of host and distant water fishing nations, Marine Policy 54 (2015) 7785.

[31] V. Christensen, P. Amorim, I. Diallo, T. Diouf, S. Guénette, J.J. Heymans, A. Mendy, T. Mahfoudh Sidi, M. Palomares, B. Samb, Trends in fish biomass off Northwest Africa, 19602000, West African marine ecosystems: models and fisheries impacts. Fisheries Centre Research Reports 12(7) (2004) 215-220.

[32] C. Mora, R.A. Myers, T.J. Pitcher, C. De Young, R. Sumaila, D. Zeller, R. Watson, F.J. Gaston, B. Worm, Management effectiveness of the world's marine fisheries., PLoS Biology 7(6) (2009) e1000131.

[33] D. Pauly, D. Belhabib, R. Blomeyer, W. Cheung, A. Cisneros-Montemayor, D. Copeland, S. Harper, V. Lam, Y. Mai, F. Le Manach, H. Österblom, K. Mok, L. van der Meer, A. Sanz, S. Shon, U. Sumaila, W. Swartz, R. Watson, Y. Zhai, D. Zeller, China's distant water fisheries in the 21st century., Fish and Fisheries 15(3) (2013) 474-488.

[34] C.A. Stock, J.G. John, R.R. Rykaczewski, R.G. Asch, W.W.L. Cheung, J.P. Dunne, K.D. Friedland, V.W.Y. Lam, J.L. Sarmiento, R.A. Watson, Reconciling fisheries catch and ocean productivity, PNAS 114(8) (2017) E1441-E1449.

[35] E.K. Pikitch, J.R. Konstantine, T.E. Essington, C. Santora, D. Pauly, R. Watson, U.R. Sumaila, P.D. Boersma, I.L. Boyd, D.O. Conover, P. Cury, S.S. Heppell, E.D. Houde, M. 
Mangel, E. Plaganyi-Lloyd, K. Sainsbury, R.S. Steneck, T.M. Geers, N. Gownaris, S.P. Munch, The global contribution of forage fish to marine fisheries and ecosystems, Fish and Fisheries 15(1) (2014) 43-64.

[36] T.E. Essington, H.E. Froehlich, E.E. Hodgson, L.E. Koehn, K.L. Oken, M.C. Siple, C.C. Stawitz, Fishing amplifies forage fish population collapses, Proceedings of the National Academy of Sciences 112(21) (2014) 6648-6652.

[37] K. Kaschner, V. Karpouzi, R. Watson, D. Pauly, Forage fish consumption by marine mammals and seabirds, in: J. Alder, D. Pauly (Eds.) Fisheries Centre Research Reports, Fisheries Centre, University of British Columbia, Vancouver, Canada, 2006, pp. 33-46. [38] K. Kaschner, R. Watson, A. Trites, D. Pauly, Mapping world-wide distributions of marine mammal species using a relative environmental suitability (RES) model, Marine Ecology Progress Series 316 (2006) 285-310.

[39] M. Paleczny, R.W. Furness, E. Hammill, V. Karpouzi, M. LeCorre, A.W. Trites, R. Watson, D. Pauly, Are global marine fisheries starving seabirds?, 2nd International Marine Conservation Congress, Victoria, Canada, 2011.

[40] V.S. Karpouzi, R. Watson, D. Pauly, Modelling and mapping resource overlap between seabirds and fisheries on a global scale: a preliminary assessment, CM-International Council for the Exploration of the Sea 343 (2007) 87-99.

[41] R. Parker, P. Tyedmers, Fuel consumption of global fishing fleets: current understanding and knowledge gaps, Fish and Fisheries 16(4) (2015) 684-696.

[42] P.H. Tyedmers, R. Watson, D. Pauly, Fueling global fishing fleets, AMBIO: a Journal of the Human Environment 34(8) (2005) 635-638.

[43] R. Watson, D. Pauly, The changing face of global fisheries - the 1950s vs. the 2000s, Marine Policy 42 (2013) 1-4.

[44] D. Pauly, J. Alder, E. Bennett, V. Christensen, P. Tyedmers, R. Watson, The future for fisheries, Science 302(5649) (2003) 1359-1361.

[45] R.D. McCauley, R.D. Day, K.M. Swadling, Q.P. Fitzgibbon, R.A. Watson, J.M. Semmens, Widely used marine seismic survey air gun operations negatively impact zooplankton, Nature Ecology \& Evolution (2017).

[46] X. Irigoien, T.A. Klevjer, A. Røstad, U. Martinez, G. Boyra, J.L. Acuña, A. Bode, F. Echevarria, J.I. Gonzalez-Gordillo, S. Hernandez-Leon, S. Agusti, D.L. Aksnes, C.M. Duarte, S. Kaartvedt, Large mesopelagic fishes biomass and trophic efficiency in the open ocean, Nature communications 5(3271) (2014).

[47] C.J. Brown, E.A. Fulton, A.J. Hobday, R.J. Matear, H.P. Possingham, C. Bulman, V. Christensen, R.E. Forrest, P.C. Gehrke, N.A. Gribble, Effects of climate-driven primary production change on marine food webs: implications for fisheries and conservation, Global Change Biology 16(4) (2010) 1194-1212.

[48] W.W.L. Cheung , R. Watson, D. Pauly, Signature of ocean warming in global fisheries catch., Nature 497(7449) (2013) 365-368.

[49] D.A. Kroodsma, J. Mayorga, T. Hochberg, N.A. Miller, K. Boerder, F. Ferretti, A. Wilson, B. Bergman, T.D. White, B.A. Block, P. Woods, B. Sullivan, C. Costello, B. Worm, Tracking the global footprint of fisheries., Science (in Press).

[50] C.W. Marean, When the Sea Saved Humanity

Scientific American, Scientific American, New York, 2010, pp. 40-47. 
Appendix A: Supplementary material

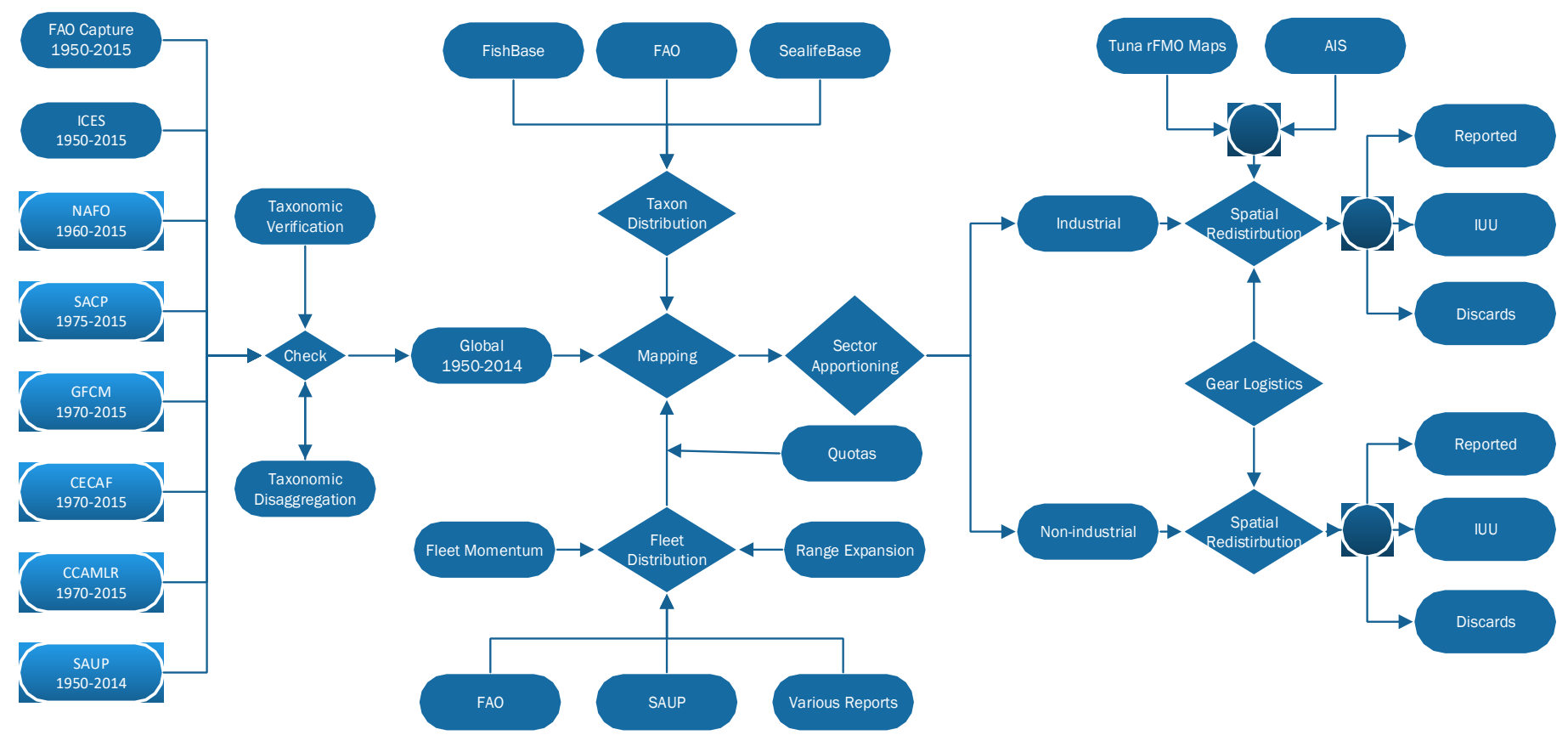

Supplementary Fig. 1. Flowchart showing data processing for the mapped global catch database.

\section{Data Structure}

For each 5-year period there two comma-separated (.csv) ASCII files. One describing catches associated with the industrial fishing sector and one describing other non-industrial fishing. The File prefix names CatchInd relate to industrial fishing and CatchNInd to other fishing. File names identify the first and last fishing year of included records. Each file has field names included in the first row.

Each file has records described below linked to an index table by a unique ID field. There is a common index file for both industrial and non-industrial fishing records

Catch Records

Supplemental Table 1. Structure of catch record data files.

\begin{tabular}{lll}
\hline Field Name & $\begin{array}{l}\text { Data } \\
\text { Type }\end{array}$ & Description \\
\hline ID & integer & Unique identifier for fishing event \\
Cell & integer & Identifier for specific 30-min spatial cell \\
Reported & real & Tonnes of reported catch (landings) \\
IUU & real & Tonnes of illegal or otherwise non-reported catch \\
Discards & real & Tonnes of any taxa discarded during fishing operation
\end{tabular}

Index Records

Supplemental Table 2. Structure of index file. 


\begin{tabular}{lll}
\hline Field Name & Data Type & Description \\
\hline ID & integer & Unique identifier for fishing event \\
Year & integer & Fishing year \\
CountryName & text & Name of country/territory \\
CommonName & text & Common name of landed taxon \\
TaxonName & text & Scientific name of landed taxon \\
FleetGearName & text & Description of general fishing gear used \\
IndReported & real & Industrial reported tonnes \\
IndIUU & real & Industrial illegal or otherwise unreported tonnes \\
IndDiscards & real & Industrial discards tonnes associated (any taxa) \\
NIndReported & real & Non-industrial reported tonnes \\
NIndIUU & real & Non-industrial illegal or otherwise unreported tonnes \\
NIndDiscards & real & Non-industrial discards tonnes associated (any taxa)
\end{tabular}

Early Historical Catch Records

The file structure and naming format for the catch files for years 1885 to 1949 is identical to those used in the catch records described previously.

Early Historical Index Records

Supplemental Table 3. Structure of historical index file.

\begin{tabular}{lll}
\hline Field Name & Data Type & Description \\
\hline ID & integer & Unique identifier for fishing event \\
Year & integer & Fishing year \\
CountryName & text & Name of country/territory \\
CommonName & text & Common name of landed taxon \\
TaxonName & text & Scientific name of landed taxon \\
FishingArea & text & Description of fishing area \\
Source & text & Source of historical data record \\
IndReported & real & Industrial reported tonnes \\
IndIUU & real & Industrial illegal or otherwise unreported tonnes \\
IndDiscards & real & Industrial discards tonnes associated (any taxa)
\end{tabular}

Similar to catch index for more modern record but there is no description of fishing gear used. There are no estimates of non-industrial catch. 